Article

\title{
Synthesis of $\mathrm{NiMoO}_{4} / 3 \mathrm{D}$-rGO Nanocomposite in
} Alkaline Environments for Supercapacitor Electrodes

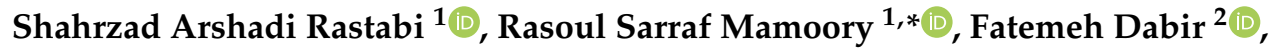 \\ Nicklas Blomquist ${ }^{3}$, Manisha Phadatare ${ }^{3}$ and Håkan Olin ${ }^{3}$ \\ 1 Department of Materials Engineering, Tarbiat Modares University, 14115111 Tehran, Iran; \\ Shd_Arshadi@yahoo.com \\ 2 Non-Metallic Materials Research Group, Niroo Research Institute, 15119-43943 Tehran, Iran; fdabir@nri.ac.ir \\ 3 Department of Natural Sciences, Mid Sweden University, 85170 Sundsvall, Sweden; \\ Nicklas.Blomquist@miun.se (N.B.); Manisha.Phadatare@miun.se (M.P.); Hakan.Olin@miun.se (H.O.) \\ * Correspondence: rsarrafm@modares.ac.ir; Tel.: +98-912-133-4979
}

Received: 29 November 2018; Accepted: 3 January 2019; Published: 9 January 2019

check for updates

\begin{abstract}
Although Graphene oxide (GO)-based materials is known as a favorable candidate for supercapacitors, its conductivity needs to be increased. Therefore, this study aimed to investigate the performance of GO-based supercapicitor with new methods. In this work, an ammonia solution has been used to remove the oxygen functional groups of GO. In addition, a facile precipitation method was performed to synthesis a $\mathrm{NiMoO}_{4} / 3 \mathrm{D}-\mathrm{rGO}$ electrode with purpose of using synergistic effects of rGO conductivity properties as well as $\mathrm{NiMoO}_{4}$ pseudocapacitive behavior. The phase structure, chemical bands and morphology of the synthesized powders were investigated by X-ray diffraction (XRD), Raman spectroscopy, and field emission secondary electron microscopy (FE-SEM). The electrochemical results showed that the $\mathrm{NiMoO}_{4} / 3 \mathrm{D}-\mathrm{rGO}$ (II) electrode, where ammonia has been used during the synthesis, has a capacitive performance of $932 \mathrm{Fg}^{-1}$. This is higher capacitance than $\mathrm{NiMoO}_{4} / 3 \mathrm{D}-\mathrm{rGO}(\mathrm{I})$ without using ammonia. Furthermore, the $\mathrm{NiMoO}_{4} / 3 \mathrm{D}-\mathrm{rGO}$ (II) electrode exhibited a power density of up to $17.5 \mathrm{~kW} \mathrm{~kg}^{-1}$ and an energy density of $32.36 \mathrm{Wh} \mathrm{kg}^{-1}$. These results showed that ammonia addition has increased the conductivity of rGO sheets, and thus it can be suggested as a new technique to improve the capacitance.
\end{abstract}

Keywords: renewable energy systems; pseudocapacitive behavior; electrochemical results; ammonia; oxygen groups

\section{Introduction}

Growing concerns about the serious environmental pollution and fossil-fuel energy crisis have attracted considerable attention to renewable and clean energy storage technologies [1]. Lithium-ion batteries, sodium-ion batteries, and supercapacitors (SCs) are currently potential energy storage devices [2]. Among them, SCs have competitive characteristics, such as high power density, long cycle life, fast charging/discharging rate [3], high safety, simple operating principles, and low maintenance costs [4,5]. Various kinds of materials have been selected to improve electrode properties. Although carbonaceous materials such as graphene and reduced GO can deliver high power density and possess high specific-area, good electrical conductivity, high chemical stability, and biocompatibility [6], faradaic electrode materials like metal oxides can provide higher capacitance and larger energy densities due to their redox reactions [7]. Recently, binary nickel-based oxides have attracted tremendous research interest because of their high theoretical capacitance and excellent electrochemical activity [8], arising from their improved electronic conductivity and surface redox reactions. Among various pseudo-active materials, $\mathrm{NiMoO}_{4}$ is an especially attractive candidate 
for pseudocapacitors, offering good stability in alkaline electrolytes, high specific capacitance and accessibility [9]. Therefore, the motivation to design and fabricate an $\mathrm{NiMoO}_{4}$ and $\mathrm{rGO}$ electrode with a novel hybrid nanostructure, which might combine the merits of both high specific capacitance originating from $\mathrm{NiMoO}_{4}$ and excellent rate capability provided by $\mathrm{rGO}$, is well founded.

Intensive studies have been carried out on the synthesis of $\mathrm{NiMoO}_{4}$ with different morphologies such as nanorods [10], nanowires [11-13], nano-spheres [14], and nanosheets [15-17] for various application. Most of these studies used the hydrothermal method [8,10-15,18-25] that requires autoclave equipped with high-pressure and high-temperature, which finally resulted to the particles with large sizes and some of the papers used sonochemical [26], microwave [27], Sol-Gel [28], electrodeposition [17], and co-precipitation method [29,30]. Obviously, $\mathrm{NiMoO}_{4}$ synthesis is much less achieved by chemical precipitation than the hydrothermal method. We also synthesized $\mathrm{NiMoO}_{4}$ and graphene simultaneously for supercapacitor application, while those papers on chemical coprecipitation were exclusively for the synthesis of just $\mathrm{NiMoO}_{4}$ and its photocatalyst properties. In the current work, a simple and low-cost chemical precipitation method was used to synthesize $\mathrm{NiMoO}_{4} / 3 \mathrm{D}-\mathrm{rGO}$ nanocomposites with no need of any specific facilities. In addition, this work studies the mechanism of formation of $\mathrm{NiMoO}_{4}$ nanoparticles on the surface of the graphene oxide and its reduction, which was not discussed in previous papers. Furthermore, there are several ways to reduce GO to rGO, one of which is the chemical reduction method. In previous works, various reduction agents such as hydrazine monohydrate [31], sodium borohydrate [32], ascorbic acid [33], ammonia borane [34], and heavy metal ions [35] have been used, while in the present research an ammonia solution has been applied.

In this work, we aim to synthesis the $\mathrm{NiMoO}_{4} / 3 \mathrm{D}-\mathrm{rGO}$ electrode through a facile precipitation method for supercapacitors with particular emphasis on reduction of GO to rGO. Therefore, synergistic effects of ammonia, metal ions and low temperature have been used to eliminate large amount of GO oxygenated groups.

\section{Experimental}

\subsection{Materials}

Graphene oxide (GO), nickel nitrate hexahydrate $\left(\mathrm{Ni}\left(\mathrm{NO}_{3}\right)_{2} \cdot 6 \mathrm{H}_{2} \mathrm{O}\right)$, sodium molybdate dihydrate $\left(\mathrm{Na}_{2} \mathrm{MoO}_{4} \cdot 2 \mathrm{H}_{2} \mathrm{O}\right)$, and potassium hydroxide $(\mathrm{KOH})$ were of reagent quality and were obtained from VWR, Sweden. Ammonia (28 wt. \%-NH $\mathrm{NH}_{3}$ ) was purchased from VWR, Sweden. Polyvinylidene fluoride (PVDF, $\left.-\left(\mathrm{C}_{2} \mathrm{H}_{2} \mathrm{~F}_{2}\right)_{n}-\right)$, its solvent dimethylformamide (DMF, $\left.\mathrm{C}_{3} \mathrm{H}_{7} \mathrm{NO}\right)$, and starch $\left(\left(\mathrm{C}_{6} \mathrm{H}_{10} \mathrm{O}_{5}\right)_{n}\right)$ were obtained from Sigma, Iran.

\subsection{Preparation of the $\mathrm{NiMoO}_{4} / 3 \mathrm{D}-r \mathrm{GO}(\mathrm{I})$ and $\mathrm{NiMoO}_{4} / 3 \mathrm{D}-\mathrm{rGO}$ (II) Nanocomposites}

Figure 1 briefly illustrates the fabrication of the $\mathrm{NiMoO}_{4} / 3 \mathrm{D}-\mathrm{rGO}(\mathrm{II})$ nanocomposite through a simple precipitation process. The $\mathrm{NiMoO}_{4} / 3 \mathrm{D}-\mathrm{rGO}$ composite was synthesized via a precipitation method in a starch environment as follows: First, $1 \mathrm{~g}$ of starch was added to $20 \mathrm{~mL}$ of distilled water at $80{ }^{\circ} \mathrm{C}$ to form a gelation suspension. Then, $1 \mathrm{mg}$ of GO was dispersed in $20 \mathrm{~mL}$ distilled water under $5 \mathrm{~min}$ ultrasonication before being added to the starch solution to form a brown suspension. To prepare an alkaline environment, $3 \mathrm{~mL}$ ammonia ( $28 \mathrm{wt}$. \%) was quickly added to the above suspension to adjust the $\mathrm{pH}$ about 10 . Then, $5 \mathrm{mM} \mathrm{Ni}\left(\mathrm{NO}_{3}\right)_{2} \cdot 6 \mathrm{H}_{2} \mathrm{O}$ and $5 \mathrm{mM} \mathrm{Na} 2 \mathrm{MoO}_{4} \cdot 2 \mathrm{H}_{2} \mathrm{O}$ were added to the above mixture in a dropwise manner and heated at $80^{\circ} \mathrm{C}$ for $1 \mathrm{~h}$, followed by $10 \mathrm{~min}$ of stirring. Subsequently, the powder was washed with distilled water to remove the impurities, and then dried at $60{ }^{\circ} \mathrm{C}$ for $24 \mathrm{~h}$ in a vacuum oven. Eventually, the final powder was calcinated in a tube furnace under Ar atmosphere at $350^{\circ} \mathrm{C}$ for $2 \mathrm{~h}$ and then cooled to room temperature naturally to obtain the $\mathrm{NiMoO}_{4} / 3 \mathrm{D}-\mathrm{rGO}$ (II) nanocomposite. The reduction of GO and the in situ formation of $\mathrm{NiMoO}_{4}$ were achieved simultaneously, causing the generation of $\mathrm{NiMoO}_{4} / \mathrm{rGO}$. The same process has been done without the addition of ammonia $\left(\mathrm{NH}_{3}\right)$ and the sample is called $\mathrm{NiMoO}_{4} / 3 \mathrm{D}-\mathrm{rGO}(\mathrm{I})$. 


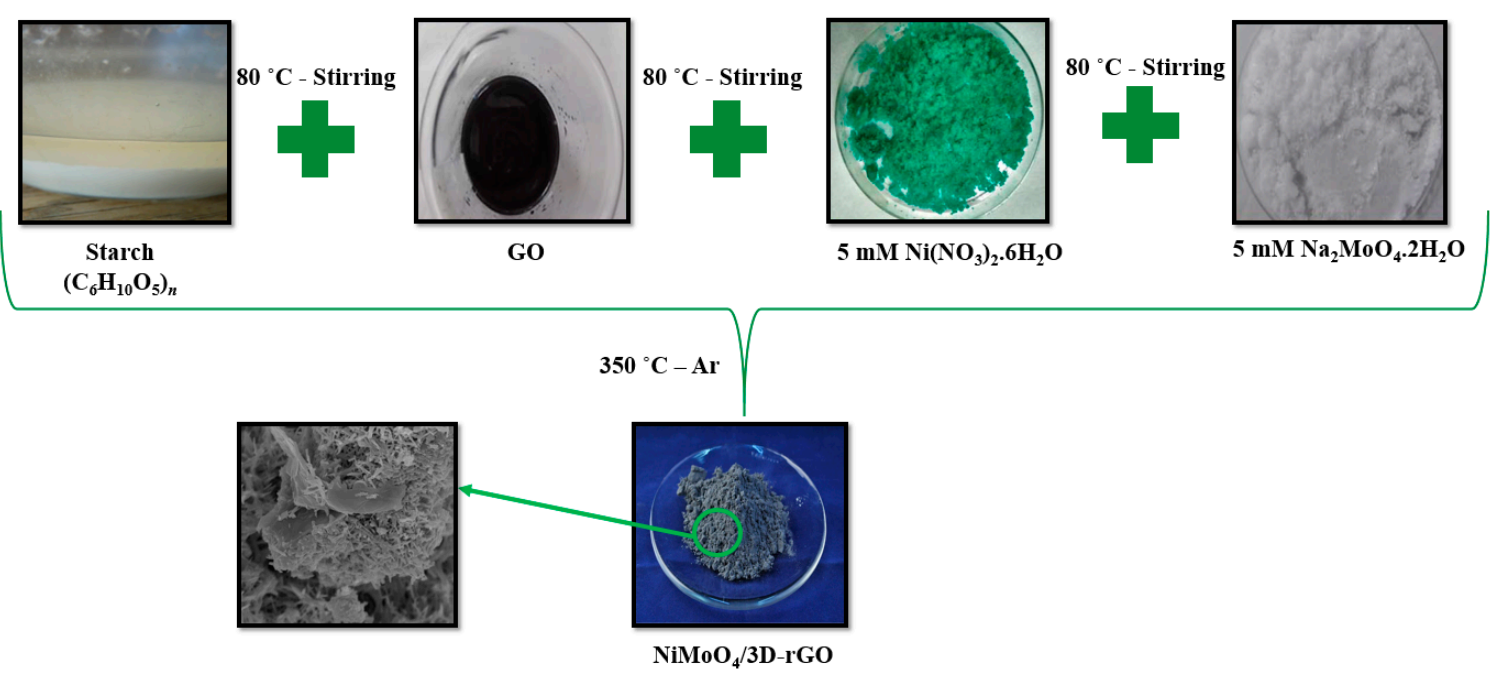

Figure 1. Schematic diagram of the synthesis process of $\mathrm{NiMoO}_{4} / 3 \mathrm{D}-\mathrm{rGO}(\mathrm{I})$.

\subsection{Electrode Fabrication of $\mathrm{NiMoO}_{4}, \mathrm{NiMoO}_{4} / 3 \mathrm{D}-\mathrm{rGO}(\mathrm{I})$, and $\mathrm{NiMoO}_{4} / 3 \mathrm{D}-\mathrm{rGO}(\mathrm{II})$ Nanocomposites}

The electrodes were prepared by mixing active material, carbon black, and polyvinylidene fluoride (PVDF) with a mass ratio of 80:10:10 in DMF, followed by ultrasonication of the slurry for $10 \mathrm{~min}$ to form a uniform solution. The Ni foam was cleaned with $\mathrm{HCl}(10 \mathrm{wt}$. \%) and ethanol during ultrasonication. Then, $2 \mathrm{mg} \cdot \mathrm{cm}^{-2}$ of the mixture was pasted onto the Ni foam $\left(1 \times 1 \mathrm{~cm}^{2}\right)$ as the working electrode before being dried in an oven at $70{ }^{\circ} \mathrm{C}$ for $24 \mathrm{~h}$.

\subsection{Material Characterization}

In this research, the following analytical systems were used to characterize the prepared powder. Structural characterization of the samples were characterized using an X-ray powder diffraction (XRD, Bruker with $\mathrm{CuK} \alpha$ radiation $(\lambda=0.1542 \mathrm{~nm})$, Sundsvall, Sweden). Field-emission scanning electron microscopy (FE-SEM, MAIA3, TESCAN, Sundsvall, Sweden) was used to investigate the morphology and microstructure of the powder. Raman spectroscopy (Raman microscope, Horiba Xplora plus, laser excitation at $532 \mathrm{~nm}$, Sundsvall, Sweden) in the frequency range of $50-3000 \mathrm{~cm}^{-1}$ was used to study the molecular bonds. A potentiostat system (VersaStat 4 with VersaStudio, Sundsvall, Sweden) was used to record the supercapacitor measurement.

\section{Results and Discussion}

X-ray diffraction analysis was used for studying the phase and structure of the samples. Figure 2 shows the XRD patterns of GO, rGO, $\mathrm{NiMoO}_{4} \mathrm{NPs} \mathrm{NiMoO}_{4} / 3 \mathrm{D}-\mathrm{rGO}(\mathrm{I})$, and $\mathrm{NiMoO}_{4} / 3 \mathrm{D}-\mathrm{rGO}$ (II) before and after calcination at $350{ }^{\circ} \mathrm{C}$. X-ray diffraction spectra of the samples were carried out at $2 \theta=10^{\circ}-80^{\circ}$ with a scanning rate of $0.02^{\circ} / \mathrm{min}$. As can be seen, GO has a sharp peak at $2 \theta=10.6^{\circ}$ corresponded with the (002), which indicates the presence of the oxygen functional groups between the layers. This peak is disappeared in rGO pattern, implying the reduction of oxygen groups after heating at $350{ }^{\circ} \mathrm{C}$. The XRD pattern of the $\mathrm{NiMoO}_{4} \mathrm{NPs}$ shows high intensity peaks, which implies the crystallinity of $\mathrm{NiMoO}_{4}$ nanoparticles. This pattern is in accordance with Card No 00-045-0142 of JCPDS (JCPDS or ICDD -International Centre for Diffraction Data) data and related to the monoclinic phase of $\mathrm{NiMoO}_{4}$. The peaks at $2 \theta=27.21^{\circ}, 30.36^{\circ}$, and $43.9^{\circ}$ which are the main characteristic peaks of the formation of the $\alpha-\mathrm{NiMoO}_{4}$ phase, show that the sample after calcination is well crystallized and $\mathrm{NiMoO}_{4} \cdot \mathrm{nH}_{2} \mathrm{O}$ has transformed to $\alpha-\mathrm{NiMoO}_{4}$ [36]. Although the results indicate that most of the phases formed are related to the $\alpha-\mathrm{NiMoO}_{4}$, a number of peaks at $2 \theta=21.12^{\circ}, 22.67^{\circ}$, and $32.07^{\circ}$ signifies the presence of the orthorhombic phase of $\mathrm{Mo}_{17} \mathrm{O}_{47}$ (01-071-0566). These peaks are respectively attributed to the (510), (001), and (521) planes of $\mathrm{Mo}_{17} \mathrm{O}_{47}$ phase. In fact, $\mathrm{Mo}_{17} \mathrm{O}_{47}$ phase consists of seventeen $\mathrm{MoO}_{3}$ phases, which has lost some of its oxygen and formed a number of vacancies, 
and eventually produced $\mathrm{Mo}_{17} \mathrm{O}_{47}$ instead of $\mathrm{Mo}_{17} \mathrm{O}_{51}$. XRD pattern of the $\mathrm{NiMoO}_{4} / 3 \mathrm{D}-\mathrm{rGO}(\mathrm{I})$ shows the exact pattern of $\alpha-\mathrm{NiMoO}_{4}$, with no diffraction peak of GO at $2 \theta=10.6^{\circ}$. The peak at $2 \theta=22.67^{\circ}$ has been broaden rather than $\alpha-\mathrm{NiMoO}_{4}$ pattern, which is the same as rGO pattern. It can be concluded that in this case, the oxygenated groups of GO has been eliminated. The ammonia molecule is consisted of one nitrogen and three hydrogen atoms and due to the presence of lone pair on the nitrogen atom, this molecule is a strong source of electrons which is expected that it can eliminate oxygen groups of GO sheets. In order to investigate the role of the ammonia solution in the reduction process of $\mathrm{GO}$, ammonia solution was added to $\mathrm{GO}$ suspension to adjust the $\mathrm{pH}$ about 10 . After drying the sample at $60{ }^{\circ} \mathrm{C}$ without further heat treatment, its color changed from brown to black. According to some papers, changing in color can be the evidence of converting GO into rGO [37]. This sample is characterized before and after calcination at $350{ }^{\circ} \mathrm{C}$. According to the XRD pattern of the $\mathrm{NiMoO}_{4} / 3 \mathrm{D}-\mathrm{rGO}$ (II) nanocomposite before calcination, there is no peak of GO at $2 \theta=10.6^{\circ}$, which indicates that before heat treatment, ammonia caused reduction of GO sheets. Furthermore, the XRD pattern of the $\mathrm{NiMoO}_{4} / 3 \mathrm{D}-\mathrm{rGO}$ (II) nanocomposite after calcination reveals a peak at $43.3^{\circ}$, which corresponds to $\mathrm{N}-\mathrm{rGO}$, based on data from [38]. It reveals that nitrogen of ammonia has been doped into the rGO network at $350^{\circ} \mathrm{C}$. In addition, the peak at $2 \theta=23.1^{\circ}(\mathrm{d} \sim 3.4 \AA)$, while the GO has a peak at $2 \theta=10.6^{\circ}(\mathrm{d} \sim 8.3 \AA)$. The large space between the layers in GO is attributed to the presence of hydrocarbons, the oxygen-containing groups, and also the $\mathrm{H}_{2} \mathrm{O}$ molecules at the edges and the distance between the sheets. In other words, decrease in the space between layers of graphene sheets in the $\mathrm{NiMoO}_{4} / 3 \mathrm{D}-\mathrm{rGO}$ (II) sample is a reason for the successful reduction of the GO sheets [39]. Results show that oxygen-containing groups can easily accept free electrons of ammonia to separate the carbon-oxygen bond, repaired $\pi$ bands and form carbon radicals on GO sheets, and lead to the formation of rGO [37].

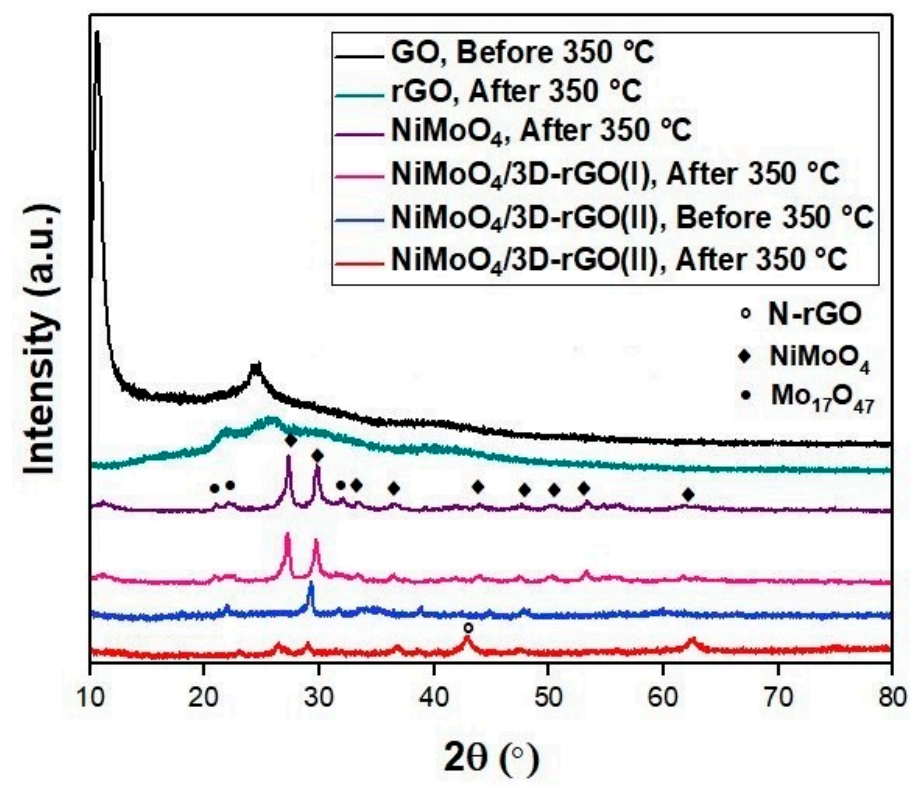

Figure 2. The XRD pattern of $\mathrm{GO}, \mathrm{rGO}, \mathrm{NiMoO}_{4} \mathrm{NPs}, \mathrm{NiMoO}_{4} / 3 \mathrm{D}-\mathrm{rGO}(\mathrm{I})$, and $\mathrm{NiMoO}_{4} / 3 \mathrm{D}-\mathrm{rGO}(\mathrm{II})$ before and after heating at $350{ }^{\circ} \mathrm{C}$.

To compare the reduction rate of $\mathrm{GO}$ in the $\mathrm{NiMoO}_{4} / 3 \mathrm{D}-\mathrm{rGO}(\mathrm{II})$ nanocomposite with that of the $\mathrm{NiMoO}_{4} / 3 \mathrm{D}-\mathrm{rGO}(\mathrm{I})$ nanocomposite, the Raman spectra were measured for GO, $\mathrm{NiMoO}_{4} / 3 \mathrm{D}-\mathrm{rGO}(\mathrm{I})$, and $\mathrm{NiMoO}_{4} / 3 \mathrm{D}-\mathrm{rGO}$ (II) nanocomposites (shown in Figure 2). The Raman spectra of the pure GO (Figure 3a) shows that the D and G peaks are located at $1347.64 \mathrm{~cm}^{-1}$ and $1574.98 \mathrm{~cm}^{-1}$, respectively. The relative intensity ratio of the peaks $\left(\mathrm{I}_{\mathrm{D}} / \mathrm{I}_{\mathrm{G}}\right)$ is a measure of the disorder degree, and its value is approximately 0.98 for GO [23]. In both spectra of the $\mathrm{NiMoO}_{4} / 3 \mathrm{D}-\mathrm{rGO}(\mathrm{I})$ and $\mathrm{NiMoO}_{4} / 3 \mathrm{D}-\mathrm{rGO}(\mathrm{II})$ nanocomposites, the characteristic peaks at $969 \mathrm{~cm}^{-1}(\mathrm{Mo}=\mathrm{O}), 928 \mathrm{~cm}^{-1}(\mathrm{Mo}=\mathrm{O})$, 
and $697 \mathrm{~cm}^{-1}$ (Ni-O-Mo) and some medium-intensity peaks at $394 \mathrm{~cm}^{-1}(\mathrm{Mo}-\mathrm{O})$ and $325 \mathrm{~cm}^{-1}$ (Mo-O-Mo) belong to the $\alpha$-phase $\mathrm{NiMoO}_{4}[10,40,41]$ according to $\mathrm{NiMoO}_{4}$ spectra (Figure 3a). The Raman spectra of the $\mathrm{NiMoO}_{4} / 3 \mathrm{D}-\mathrm{rGO}(\mathrm{I})$ nanocomposite (Figure $3 \mathrm{~b}$ ) shows that after chemical reduction of $\mathrm{GO}$ to $\mathrm{rGO}$, the $\mathrm{I}_{\mathrm{D}} / \mathrm{I}_{\mathrm{G}}$ ratio slightly increased from $0.98(\mathrm{GO})$ to $1.02(\mathrm{rGO})$, due to the increase in the amount of defects in $\mathrm{rGO}$. In comparison to the $\mathrm{NiMoO}_{4} / 3 \mathrm{D}-\mathrm{rGO}(\mathrm{I})$, the $\mathrm{I}_{\mathrm{D}} / \mathrm{I}_{\mathrm{G}}$ ratio of $\mathrm{NiMoO}_{4} / 3 \mathrm{D}-\mathrm{rGO}$ (II) nanocomposite (Figure 3c) was calculated to be approximately 1.049, which is higher than that of the $\mathrm{NiMoO}_{4} / 3 \mathrm{D}-\mathrm{rGO}(\mathrm{I})$ nanocomposite (1.02). This finding shows that ammonia reduced more oxygenated groups in the $\mathrm{NiMoO}_{4} / 3 \mathrm{D}-\mathrm{rGO}$ (II) sample. In addition, the Raman spectra of the $\mathrm{NiMoO}_{4} / 3 \mathrm{D}-\mathrm{rGO}$ (II) nanocomposite (Figure 3c) shows that the D and G peaks redshifted to the wavenumbers at approximately $1344.89 \mathrm{~cm}^{-1}$ and $1574.98 \mathrm{~cm}^{-1}$, respectively, compared to $1339.39 \mathrm{~cm}^{-1}$ and $1577.65 \mathrm{~cm}^{-1}$ in $\mathrm{NiMoO}_{4} / 3 \mathrm{D}-\mathrm{rGO}(\mathrm{I})$. The Raman results confirm that although the $\mathrm{GO}$ has been reduced in the presence of $\mathrm{NiMoO}_{4} \mathrm{NPs}$, using an ammonia solution during synthesis results in more reduction of GO. In addition, the higher intensity of $\mathrm{I}_{\mathrm{D}} / \mathrm{I}_{\mathrm{G}}$ in the $\mathrm{NiMoO}_{4} / 3 \mathrm{D}-\mathrm{rGO}$ (II) nanocomposite shows more defects and disorders in the rGO structure due to the removal of more functional groups on the surface of $\mathrm{GO}$, which results in higher conductivity and provides more active sites for electron storage $[23,42]$.

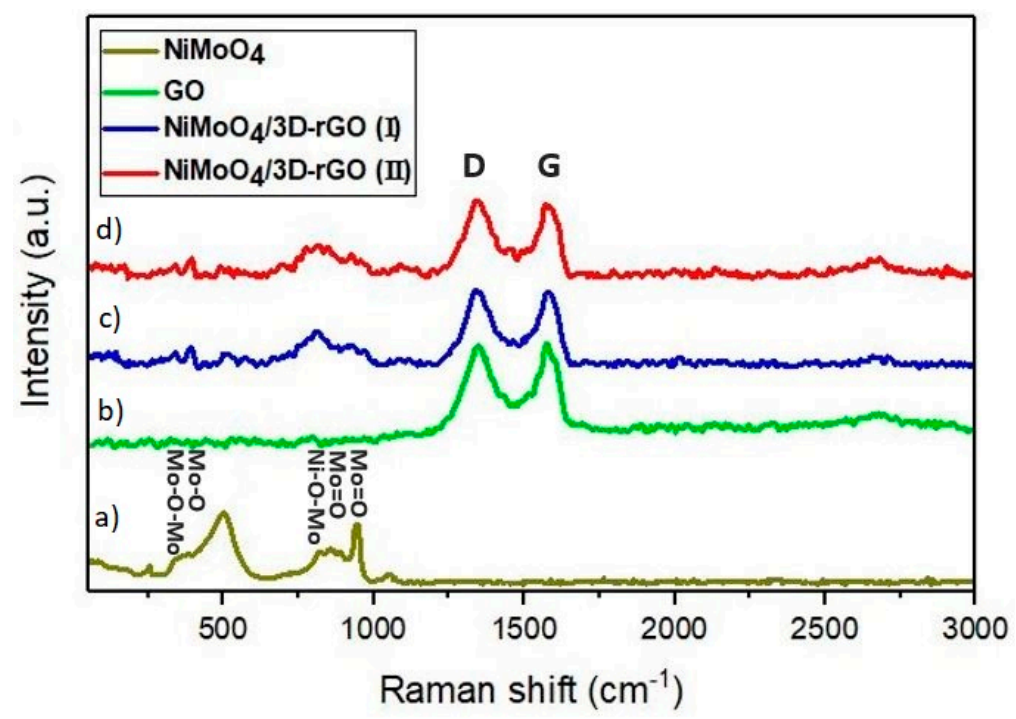

Figure 3. Raman spectra of the $\mathrm{NiMoO}_{4}$, pure GO, NiMoO $4 / 3 \mathrm{D}-\mathrm{rGO}(\mathrm{I})$, and $\mathrm{NiMoO}_{4} / 3 \mathrm{D}-\mathrm{rGO}(\mathrm{II})$ nanocomposites.

The morphologies and microstructure of the prepared $\mathrm{NiMoO}_{4} / 3 \mathrm{D}-\mathrm{rGO}$ (I) and $\mathrm{NiMoO}_{4} / \mathrm{rGO}$ (II) nanocomposites were investigated by SEM (Figure 4). The SEM images of the both nanocomposites show a 3D interconnected network consisting of $\mathrm{NiMoO}_{4}$ nanorods and $\mathrm{rGO}$ sheets. According to the SEM images of $\mathrm{NiMoO}_{4} / 3 \mathrm{D}-\mathrm{rGO}(\mathrm{I})$ nanocomposite, it seems that graphene oxide sheets were the nucleation centers for growing $\mathrm{NiMoO}_{4}$ nanorods and they have been anchored the surface of reduced graphene sheets. This probably happened due to the strong electrostatic interaction between the nanorods and the reduced graphene oxide. Whereas the SEM images of $\mathrm{NiMoO}_{4} / 3 \mathrm{D}-\mathrm{rGO}$ (II) nanocomposite consisted of two different phases. It shows thick rGO sheets which can be interpret as graphite sheets. This phenomena can be attributed to the ammonia effect on reduction of the sheets. Another phase is $\mathrm{NiMoO}_{4}$ nanorods which due to magnetic interaction has gathered together and made a separate porous structure. The results showed that starch as an environmentally friendly surfactant prevented the agglomeration of particles and eventually turned into gases $\left(\mathrm{CO}-\mathrm{CO}_{2}\right)$ at $350{ }^{\circ} \mathrm{C}$ and resulted in a porous structure nanocomposite. Such a nanostructured morphology can provide more voids and a short diffusion path between the electrode material and the electrolyte which increases electrolyte diffusion and accessibility to reaction sites for more energy storage [23]. 

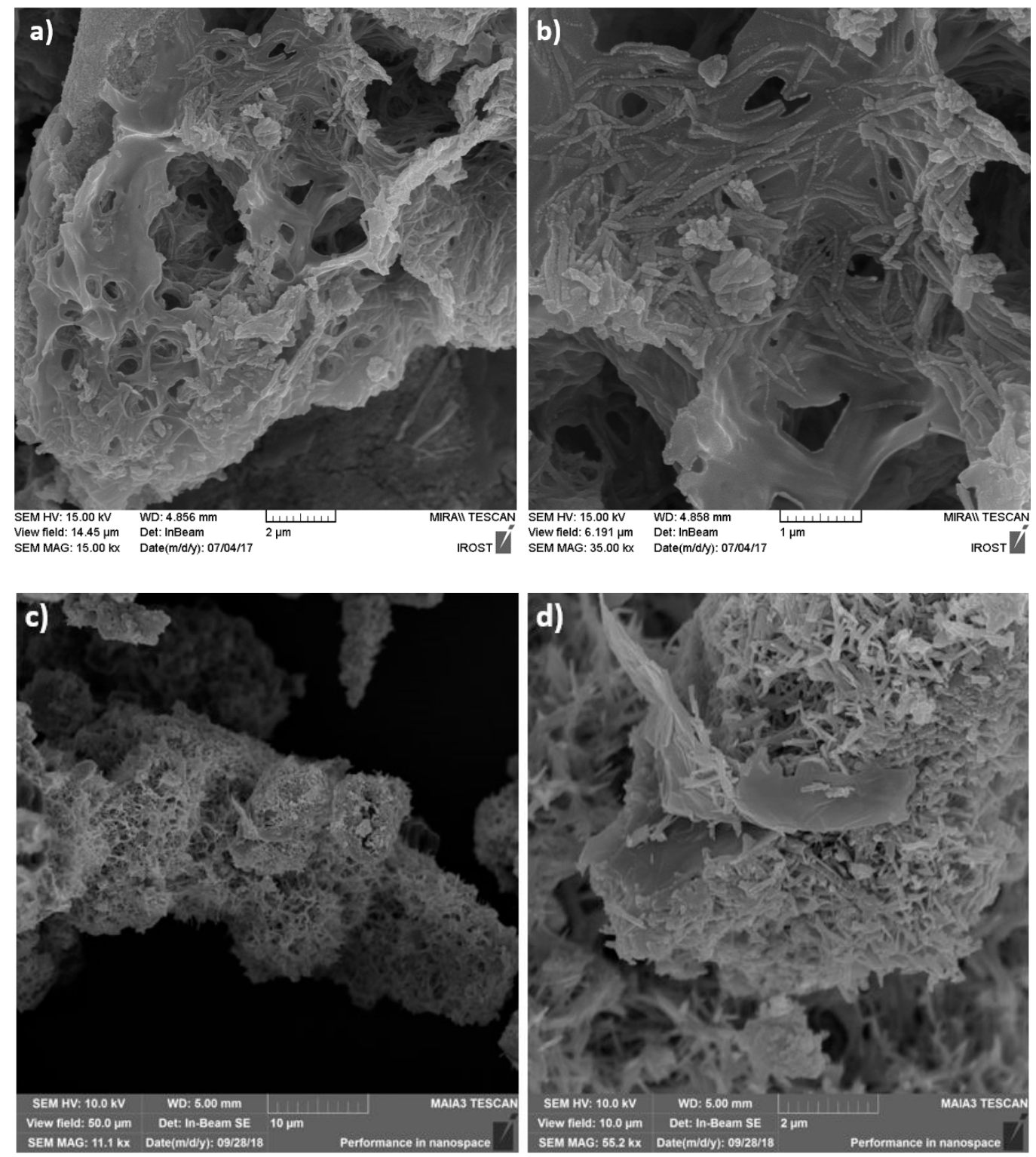

Figure 4. SEM images of $(\mathbf{a}, \mathbf{b}) \mathrm{NiMoO}_{4} / 3 \mathrm{D}-\mathrm{rGO}(\mathrm{I})$ and $(\mathbf{c}, \mathbf{d}) \mathrm{NiMoO}_{4} / \mathrm{rGO}(\mathrm{II})$ nanocomposites with two different magnifications.

A possible formation mechanism for the synthesis of the $\mathrm{NiMoO}_{4} / 3 \mathrm{D}-\mathrm{rGO}(\mathrm{I})$ nanocomposite is schematically shown in Figure 5. It is well known that, $-\mathrm{COOH}$ or $-\mathrm{OH}$ oxygen-containing functional groups of GO sheets are the nucleation centers for combining $\mathrm{Ni}^{2+}$ and $\mathrm{MoO}_{4}{ }^{2-}$ ions to form $\mathrm{NiMoO}_{4}$. It has been reported that during the adsorption process, the release of the proton $\left(\mathrm{H}^{+}\right)$of $-\mathrm{COOH}$ or $-\mathrm{OH}$ functional groups to the solution results in a decrease of the equilibrium $\mathrm{pH}$ of the solution [43]. It can be concluded that the exchange of $\mathrm{Ni}^{2+}$ and $\mathrm{H}^{+}$on $-\mathrm{COOH}$ or $-\mathrm{OH}$ oxygenated groups can be considered to be a mechanism for the adsorption of $\mathrm{Ni}^{2+}$ onto GO, and the formation of a bridge between different GO sheets. The relevant reactions in the current study can be expressed as follows:

$$
\begin{gathered}
-\mathrm{COOH}+\mathrm{Ni}^{2+} \rightarrow-\mathrm{COONi}^{2+}+\mathrm{H}^{+} \\
-\mathrm{OH}+\mathrm{Ni}^{2+} \rightarrow-\mathrm{ONi}^{2+}+\mathrm{H}^{+} \\
-2 \mathrm{COOH}+\mathrm{Ni}^{2+} \rightarrow-\mathrm{COONiOOC}-+2 \mathrm{H}^{+} \\
-2 \mathrm{OH}+\mathrm{Ni}^{2+} \rightarrow-\mathrm{ONiO}-+2 \mathrm{H}^{+}
\end{gathered}
$$




$$
-\mathrm{COOH}+\mathrm{Ni}^{2+}+-\mathrm{OH} \rightarrow-\mathrm{COONiO}-+2 \mathrm{H}^{+} .
$$
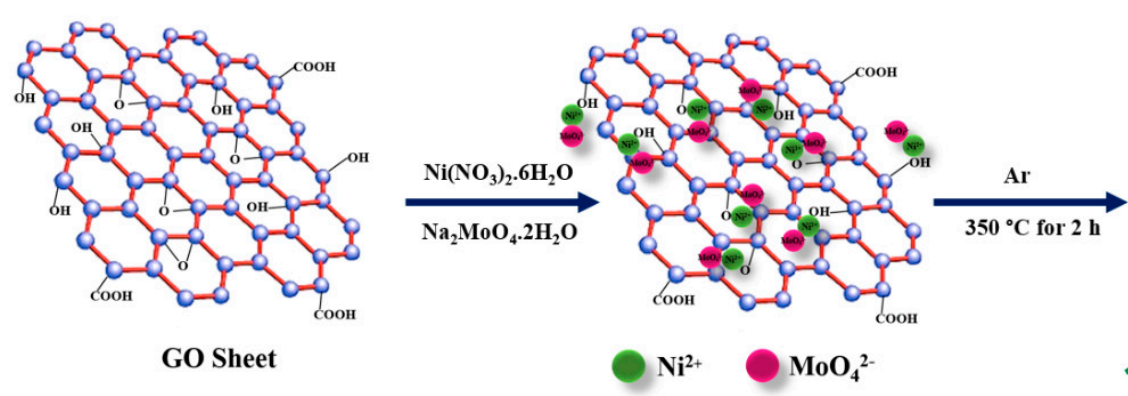

Figure 5

Schematic $\mathrm{NiMoO}_{4} / 3 \mathrm{D}-\mathrm{rGO}(\mathrm{I})$ nanocomposite.

\section{Electrochemical Studies}

The electrochemical measurements of the samples were performed in a three-electrode cell configuration at room temperature with $3 \mathrm{M} \mathrm{KOH}$ electrolyte. In this system, a platinum sheet and a saturated calomel $\mathrm{Hg} / \mathrm{Hg}_{2} \mathrm{Cl}_{2}$ electrode were used as the counter and the reference electrodes, respectively. Cyclic voltammetry $(\mathrm{CV})$ analysis was evaluated within a potential range of $0-0.7 \mathrm{~V}$ at different scan rates $\left(10-100 \mathrm{mVs}^{-1}\right)$. Figure 6a shows the $\mathrm{CV}$ curves of the $\mathrm{Ni}$ foam, $\mathrm{NiMoO}_{4}$ $\mathrm{NPs}, \mathrm{NiMoO}_{4} / 3 \mathrm{D}-\mathrm{rGO}(\mathrm{I})$, and $\mathrm{NiMoO}_{4} / 3 \mathrm{D}-\mathrm{rGO}$ (II) nanocomposites. The redox peaks confirm that the charge-storage mechanism is mainly Faradaic (battery-type) and related to reversible chemical reactions of $\mathrm{Ni}(\mathrm{II}) \leftrightarrow \mathrm{Ni}(\mathrm{III})+\mathrm{e}^{-}$[44] which can be expressed as follows [3,45]:

$$
\begin{gathered}
\mathrm{Ni}(\mathrm{OH})_{2}+\mathrm{OH}^{-} \leftrightarrow \mathrm{NiOOH}+\mathrm{H}_{2} \mathrm{O}+\mathrm{e}^{-} \\
\mathrm{NiOOH}+\mathrm{OH}^{-} \leftrightarrow \mathrm{NiO}_{2}+\mathrm{H}_{2} \mathrm{O}+\mathrm{e}^{-} .
\end{gathered}
$$

Mo atoms do not take part in the redox reaction. The main function of Mo element was to improve the conductivity of Nickel molybdate, thereby contributing in increasing specific capacitance and it does not show any redox peak in CV curves [46,47]. As seen, the area surrounded by the CV curve of the $\mathrm{NiMoO}_{4} / 3 \mathrm{D}-\mathrm{rGO}$ (II) hybrid electrode is larger and the redox current is higher than that of the $\mathrm{NiMoO}_{4} / 3 \mathrm{D}-\mathrm{rGO}$ (I) electrode, indicating much more specific capacitance of the $\mathrm{NiMoO}_{4} / 3 \mathrm{D}-\mathrm{rGO}$ (II) electrode. More capacitance of $\mathrm{NiMoO}_{4} / 3 \mathrm{D}-\mathrm{rGO}$ (II) supports the fact that removing more oxygenated surface functional groups of GO can provide more active sites for storing energy and increasing conductivity. Furthermore, the potential difference $(\Delta \mathrm{E})$ between the reduction and oxidation peaks of the $\mathrm{NiMoO}_{4} / 3 \mathrm{D}-\mathrm{rGO}$ (II) composite is $160 \mathrm{mV}$, which is approximately $81 \mathrm{mV}$ smaller than that of the $\mathrm{NiMoO}_{4} / 3 \mathrm{D}-\mathrm{rGO}(\mathrm{I})$ electrode $(241 \mathrm{mV}$, Figure $6 \mathrm{a})$, indicating better electrochemical reversibility of $\mathrm{NiMoO}_{4} / 3 \mathrm{D}-\mathrm{rGO}$ (II) due to more reduction of GO sheets in the presence of ammonia [48].

Figure $6 \mathrm{~b}$ illustrates the $\mathrm{CV}$ curves of the $\mathrm{NiMoO}_{4} / 3 \mathrm{D}-\mathrm{rGO}$ (II) electrode at the scan rates of $10-100 \mathrm{mVs}^{-1}$ in the potential window of $0-0.7 \mathrm{~V}$. With increased scan rates, the anodic and cathodic currents increase, suggesting fast redox reactions at the electrode/electrolyte contact surface at high scan rates, which results in lower specific capacitance [22]. Due to the presence of graphene oxide sheets, in addition to the Faradaic and electrochemical reactions of $\mathrm{NiMoO}_{4}$, formation of the electrical double-layer can lead to more charge storage in the system [49]. According to the resulting curves, it is noteworthy that by increasing the scan rate, even at the scan rate of $100 \mathrm{mVs}^{-1}$, redox peaks are still observed, indicating good chemical stability and conductivity in the hybrid structure of the electroactive materials [50]. 

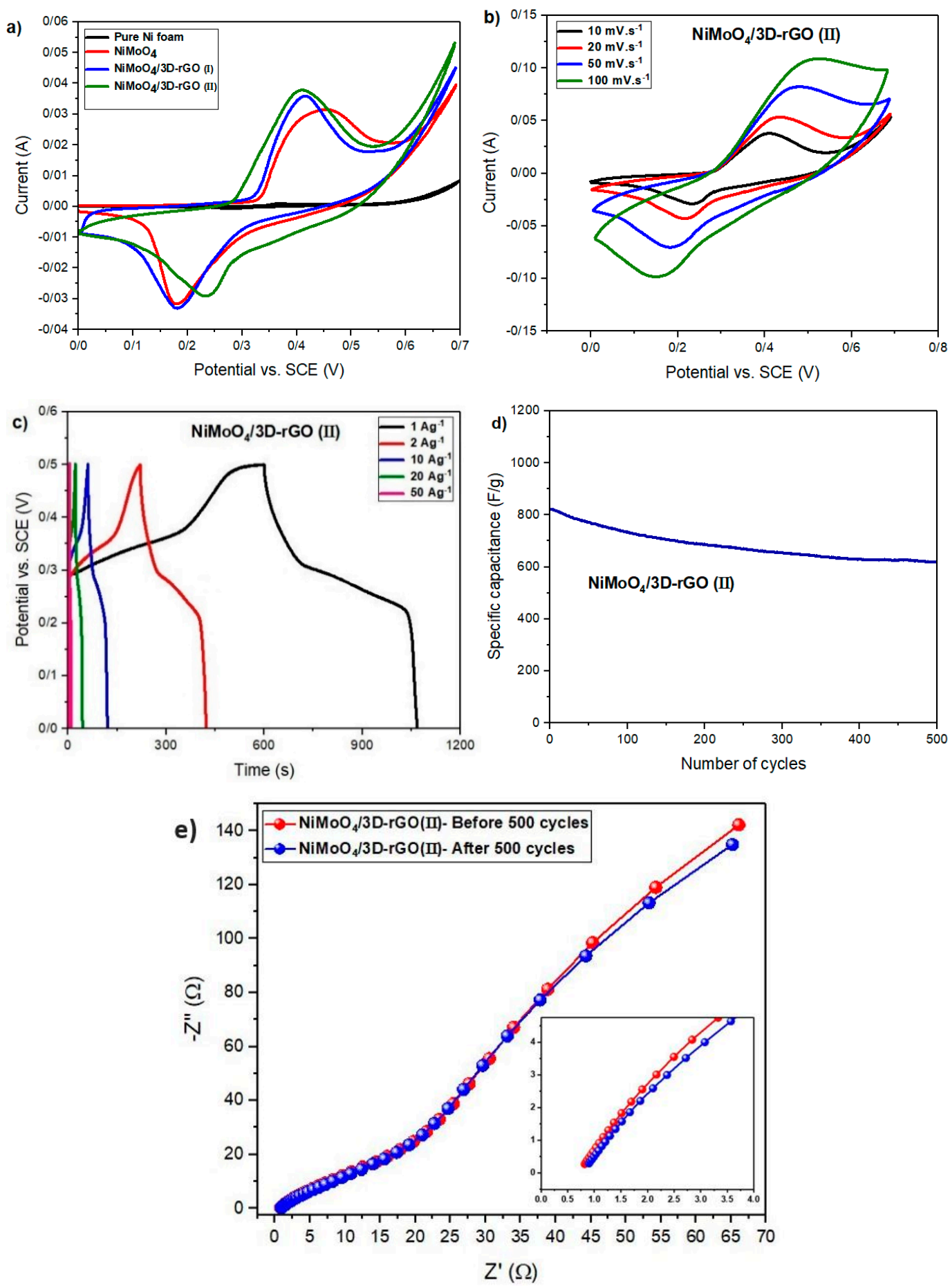

Figure 6. (a) Cyclic voltammetry (CV) curves of the $\mathrm{Ni}$ foam, $\mathrm{NiMoO}_{4} \mathrm{NPs}, \mathrm{NiMoO}_{4} / 3 \mathrm{D}-\mathrm{rGO}(\mathrm{I})$, and $\mathrm{NiMoO}_{4} / 3 \mathrm{D}-\mathrm{rGO}(\mathrm{II})$ nanocomposites at scan rates of $10 \mathrm{mVs}^{-1}$; (b) $\mathrm{CV}$ curves of the $\mathrm{NiMoO}_{4} / 3 \mathrm{D}-\mathrm{rGO}$ (II) nanocomposite at different scan rates of $10-100 \mathrm{mVs}^{-1}$; (c) GCD curves of the $\mathrm{NiMoO}_{4} / 3 \mathrm{D}-\mathrm{rGO}$ (II) nanocomposite at various current densities (1-50 $\mathrm{Ag}^{-1}$ ); and (d) cyclic stability of the $\mathrm{NiMoO}_{4} / 3 \mathrm{D}-\mathrm{rGO}$ (II) electrode after 1000 cycles; and (e) The Nyquist plots of the $\mathrm{NiMoO}_{4} / 3 \mathrm{D}-\mathrm{rGO}(\mathrm{II})$ electrode before and after 500 cycles.

Galvanostatic charge-discharge (GCD) tests were further performed to evaluate the capacitance of the electrodes at current densities of $1-50 \mathrm{Ag}^{-1}$. Figure $6 \mathrm{c}$ illustrates the GCD curves of the $\mathrm{NiMoO}_{4} / 3 \mathrm{D}-\mathrm{rGO}$ (II) electrode between $0 \mathrm{~V}$ and $0.5 \mathrm{~V}$. A pair of voltage plateaus appear at $\sim 0.29$ and $\sim 0.23 \mathrm{~V}$ and nonlinear behavior of the GCD curves, revealing the pseudocapacitive features of $\mathrm{Ni}^{2+}$ 
ions of the $\mathrm{NiMoO}_{4} / 3 \mathrm{D}-\mathrm{rGO}(\mathrm{II})$ electrode [18]. According to the three-electrode system, the specific capacitance of the single electrode can be estimated from the cyclic voltammetry $(\mathrm{CV})$ curves and discharge curves with the Equations (8) and (9), respectively [51,52].

$$
\begin{gathered}
C_{s}=\frac{1}{\mathrm{~m} v \Delta \mathrm{V}} \int \mathrm{IdV} \\
C_{s}=\frac{\mathrm{I} \Delta \mathrm{t}}{\mathrm{m} \Delta \mathrm{V}}
\end{gathered}
$$

where $v$ is the scan rate, $\mathrm{I}$ is the discharge current, $\Delta \mathrm{t}$ the discharge time, $\mathrm{m}$ is the mass of the active material loaded on the electrode surface, and $\Delta \mathrm{V}$ refers to the potential range [51,52].

Stability behavior of the electrode was performed over repeated charge and discharge cycling. Therefore, GCD measurement for the $\mathrm{NiMoO}_{4} / 3 \mathrm{D}-\mathrm{rGO}$ (II) electrode were carried out at a current density of $2 \mathrm{Ag}^{-1}$ for approximately 500 cycles in $3 \mathrm{M} \mathrm{KOH}$ electrolyte (Figure 6d). Initially, the $\mathrm{NiMoO}_{4} / 3 \mathrm{D}-\mathrm{rGO}$ (II) electrode showed a significant decrease in the capacitance up to first 200 cycles. However, after 200 cycles the capacitance decreased slowly and at the end of 500 cycles, the capacitance dropped to $76 \%$ of its initial value. Good cycle stability of the $\mathrm{NiMoO}_{4} / 3 \mathrm{D}-\mathrm{rGO}(\mathrm{II})$ is due to the porous structure with $\mathrm{NiMoO}_{4}$ rod morphology and low amount of oxygenated groups of $\mathrm{GO}$ after reduction in an alkaline environment.

Figure 6e illustrates the electrochemical impedance spectra of the $\mathrm{NiMoO}_{4} / 3 \mathrm{D}-\mathrm{rGO}$ (II) electrode before and after 500 cycles over the frequency range of $0.1 \mathrm{~Hz}$ to $100 \mathrm{kHz}$ by applying a $10 \mathrm{mV}$-AC voltage. The Nyquist plots are usually consisted of two segments; the small semicircle in the high frequency region and the approximately straight line in the low frequency region. The diameter of the semicircle corresponds to the charge transfer resistance $\left(\mathrm{R}_{\mathrm{ct}}\right)$ during Faradaic redox reaction. As can be seen, the Nyquist plots of both spectra show a negligible semi-circle in the high frequency region because of fast faradaic reactions, implying low $R_{c t}$ and good charge transfer [53]. The intercept on the real axis at the beginning of the semicircle part determine the ESR $\left(R_{S}\right)$ which is combination of electrode material resistance, ionic resistance of electrolyte and contact resistance between current collector and electrode material [54]. ESR for $\mathrm{NiMoO}_{4} / 3 \mathrm{D}-\mathrm{rGO}(\mathrm{II})$ electrode before cycling is 0.82 and after cycling the ESR value has increased to 0.9. Moreover, the linear line in low frequency region implies Warburg impedance $\left(\mathrm{Z}_{\mathrm{W}}\right)$ attributed to $\mathrm{OH}^{-}$ions diffusion of electrolyte. The more vertical the line, the closer to ideal capacitive behavior of the nanocomposite [53]. In the EIS plot of $\mathrm{NiMoO}_{4} / 3 \mathrm{D}-\mathrm{rGO}(\mathrm{II})$ electrode before 500 cycles, the straight line leans more towards the vertical Z" axis, indicating a better capacitive performance and lower ion diffusion resistance of this electrode in contrast to $\mathrm{NiMoO}_{4} / 3 \mathrm{D}-\mathrm{rGO}(\mathrm{II})$ electrode after 500 cycles.

\section{Conclusions}

A simple precipitation approach is demonstrated to synthesize the $\mathrm{NiMoO}_{4} \mathrm{NPs}$, $\mathrm{NiMoO}_{4} / 3 \mathrm{D}-\mathrm{rGO}(\mathrm{I})$ and $\mathrm{NiMoO}_{4} / 3 \mathrm{D}-\mathrm{rGO}(\mathrm{II})$ nanocomposite electrodes. The results showed that GO sheets were successfully reduced due to the disappearance of $2 \theta=10.6^{\circ}$ peak in XRD patterns and increase of $\mathrm{I}_{\mathrm{D}} / \mathrm{I}_{\mathrm{G}}$ ratio in Raman spectrum. It can be concluded that the synergistic effect of the ammonia, metal ions and temperature benefited the deoxygenation of GO sheets. In general, addition of ammonia provided the possibility of GO deoxygenating and subsequent thermal treatment will restore the $\mathrm{C}=\mathrm{C}$ bond to convert $\mathrm{GO}$ to reduced graphene oxide. The $\mathrm{NiMoO}_{4} / 3 \mathrm{D}-\mathrm{rGO}(\mathrm{I})$ and $\mathrm{NiMoO}_{4} / 3 \mathrm{D}-\mathrm{rGO}$ (II) electrodes demonstrated specific capacitances of $790 \mathrm{Fg}^{-1}$ and $932 \mathrm{Fg}^{-1}$, at a current density of $1 \mathrm{Ag}^{-1}$. An improved capacitive performance of the $\mathrm{NiMoO}_{4} / 3 \mathrm{D}-\mathrm{rGO}$ (II) electrode is attributed to the pseudocapacitance behavior of $\mathrm{NiMoO}_{4}$ and the elimination of oxygen-containing groups which will be beneficial to the increase in the electronic conductivity of resulting rGO. In addition, the $\mathrm{NiMoO}_{4} / 3 \mathrm{D}-\mathrm{rGO}$ (II) electrode showed a good cycle life with $76 \%$ retention of the initial specific capacitance after 500 cycles. 
Author Contributions: S.A.R.; Investigation, Synthesize and Writing—original draft, R.S.M.; Supervision, F.D.; Software, N.B.; Editing and Formal analysis, M.P.; Software, and H.O.; Supervision and editing.

Funding: This research received no external funding.

Acknowledgments: The authors acknowledge Tarbiat Modares University and Mid Sweden University for providing the facilities and technical assistance for this research. We thank the honorable supervisors, Magnus Hummelgård, and all of the personnel who work in the research.

Conflicts of Interest: The authors declare no conflict of interest.

\section{References}

1. Zuo, W.; Li, R.; Zhou, C.; Li, Y.; Xia, J.; Liu, J. Battery-Supercapacitor Hybrid Devices: Recent Progress and Future Prospects. Adv. Sci. 2017, 4, 1600539. [CrossRef] [PubMed]

2. Sun, F.; Gao, J.; Zhu, Y.; Pi, X.; Wang, L.; Liu, X.; Qin, Y. A high performance lithium ion capacitor achieved by the integration of a Sn-C anode and a biomass-derived microporous activated carbon cathode. Sci. Rep. 2017, 7, 40990. [CrossRef] [PubMed]

3. Yan, A.L.; Wang, X.C.; Cheng, J.P. Research Progress of NiMn Layered Double Hydroxides for Supercapacitors: A Review. Nanomaterials 2018, 8, 747. [CrossRef]

4. Chiam, S.L.; Lim, H.N.; Hafiz, S.M.; Pandikumar, A.; Huang, N.M. Electrochemical Performance of Supercapacitor with Stacked Copper Foils Coated with Graphene Nanoplatelets. Sci. Rep. 2018, 8, 3093. [CrossRef] [PubMed]

5. Huang, L.; Zhang, W.; Xiang, J.; Xu, H.; Li, G.; Huang, Y. Hierarchical core-shell $\mathrm{NiCo}_{2} \mathrm{O}_{4} @ \mathrm{NiMoO}_{4}$ nanowires grown on carbon cloth as integrated electrode for high-performance supercapacitors. Sci. Rep. 2016, 6, 31465. [CrossRef] [PubMed]

6. Wang, C.; Zhou, E.; He, W.; Deng, X.; Huang, J.; Ding, M.; Wei, X.; Liu, X.; Xu, X. NiCo $\mathrm{O}_{4}-\mathrm{Based}$ Supercapacitor Nanomaterials. Nanomaterials 2017, 7, 41. [CrossRef] [PubMed]

7. Owusu, K.A.; Qu, L.; Li, J.; Wang, Z.; Zhao, K.; Yang, C.; Zhou, L. Low-crystalline iron oxide hydroxide nanoparticle anode for high-performance supercapacitors. Nat. Commun. 2017, 8, 14264. [CrossRef] [PubMed]

8. Xue, W.D.; Wang, W.J.; Fu, Y.F.; He, D.X.; Zeng, F.Y.; Zhao, R. Rational synthesis of honeycomb-like $\mathrm{NiCo}_{2} \mathrm{O}_{4} @ \mathrm{NiMoO}_{4}$ core/shell nanofilm arrays on $\mathrm{Ni}$ foam for high-performance supercapacitors. Mater. Lett. 2017, 186, 34-37. [CrossRef]

9. Xiong, X.; Ding, D.; Chen, D.; Waller, G.; Bu, Y.; Wang, Z.; Liu, M. Three-dimensional ultrathin $\mathrm{Ni}(\mathrm{OH})_{2}$ nanosheets grown on nickel foam for high- performance supercapacitors. Nano Energy 2015, 11, $154-161$. [CrossRef]

10. Jothi, P.R.; Kannan, S.; Velayutham, G. Enhanced methanol electro-oxidation over in-situ carbon and graphene supported one dimensional $\mathrm{NiMoO}_{4}$ nanorod. Power Sources 2015, 277, 350-359. [CrossRef]

11. Guo, D.; Zhang, P.; Zhang, H.; Yu, X.; Zhu, J.; Li, Q.; Wang, T. NiMoO 4 nanowires supported on Ni foam as novel advanced electrodes for supercapacitors. J. Mater. Chem. A 2013, 1, 9024-9027. [CrossRef]

12. Guo, D.; Luo, Y.; Yu, X.; Li, Q.; Wang, T. High performance $\mathrm{NiMoO}_{4}$ nanowires supported on carbon cloth as advanced electrodes for symmetric supercapacitors. Nano Energy 2014, 8, 174-182. [CrossRef]

13. Liu, X.; Zhang, K.; Yang, B.; Song, W.; Liu, Q.; Jia, F.; Qin, S.; Chen, W.; Li, J.; Zhang, Z. Three-Dimensional Graphene Supported Nickel Molybdate Nanowires as Novel Ultralight and Flexible Electrode for Supercapacitors. Mater. Lett. 2016, 164, 401-404. [CrossRef]

14. Cai, D.; Wang, D.; Liu, B.; Wang, Y.; Liu, Y.; Wang, L.; Li, H.; Huang, Ch.; Li, Q.; Wang, T. Comparison of the Electrochemical Performance of $\mathrm{NiMoO}_{4}$ Nanorods and Hierarchical Nanospheres for Supercapacitor Applications. ACS Appl. Mater. Interfaces 2013, 5, 12905-12910. [CrossRef] [PubMed]

15. Cai, D.; Liu, B.; Wang, D.; Liu, Y.; Wang, L.; Li, H.; Wang, Y.; Wang, C.; Li, Q.; Wang, T. Enhanced performance of supercapacitors with ultrathin mesoporous $\mathrm{NiMoO}_{4}$ nanosheets. Electrochim. Acta 2014, 125, $294-301$. [CrossRef]

16. Wu, F.; Liao, Q.; Cao, F.; Li, L.; Zhang, Y. Non-noble bimetallic $\mathrm{NiMoO}_{4}$ nanosheets integrated Si photoanodes for highly efficient and stable solar water splitting. Nano Energy 2017, 34, 8-14. [CrossRef]

17. Xiao, K.; Xia, L.; Liu, G.; Wang, S.; Ding, L.X.; Wang, H. Honeycomb-like $\mathrm{NiMoO}_{4}$ Ultrathin Nanosheet Arrays for High-performance Electrochemical Energy Storage. J. Mater. Chem. A 2015, 3, 6128-6135. [CrossRef] 
18. Jinlong, L.; Miura, H.; Meng, Y. A novel mesoporous $\mathrm{NiMoO}_{4} @ \mathrm{rGO}$ nanostructure for supercapacitor applications. Mater. Lett. 2017, 194, 94-97. [CrossRef]

19. Zhang, P.; Zhou, J.; Chen, W.; Zhao, Y.; Mu, X.; Zhang, Z.; Pan, X.; Xie, E. Constructing highly-efficient electron transport channels in the $3 \mathrm{D}$ electrode materials for high-rate supercapacitors: The case of $\mathrm{NiCo}_{2} \mathrm{O}_{4} @ \mathrm{NiMoO}_{4}$ hierarchical nanostructures. Chem. Eng. Sci. 2017, 307, 687-695. [CrossRef]

20. Huang, L.; Xiang, J.; Zhang, W.; Chen, C.; Xu, H.; Huang, Y. 3D interconnected porous $\mathrm{NiMoO}_{4}$ nanoplate arrays on $\mathrm{Ni}$ foam as high-performance binder-free electrode for supercapacitors. J. Mater. Chem. A 2015, 3, 22081-22087. [CrossRef]

21. Nti, F.; Anang, D.A.; Han, J.I. Facilely synthesized $\mathrm{NiMoO}_{4} / \mathrm{CoMoO}_{4}$ nanorods as electrode material for high performance supercapacitor. Alloy Compd. 2018, 742, 342-350. [CrossRef]

22. Lin, L.; Liu, T.; Liu, J.; Sun, R.; Hao, J.; Ji, K.; Wang, Z. Facile synthesis of groove-like $\mathrm{NiMoO}_{4}$ hollow nanorods for high-performance supercapacitors. Appl. Surf. Sci. 2016, 360, 234-239. [CrossRef]

23. Li, Y.; Jian, J.; Fan, Y.; Wang, H.; Yu, L.; Cheng, G.; Sun, M. Facile one-pot synthesis of $\mathrm{NiMoO}_{4} /$ reduced graphene oxide composite as pseudocapacitors with superior performance. RSC Adv. 2016, 6, 69627-69633. [CrossRef]

24. Bakhshali-Dehkordy, R.; Aghajani, Z. Hydrothermal-Assisted Synthesis of $\mathrm{TiO}_{2} @ \mathrm{NiMoO}_{4}$ Nanocomposites and Evaluation of Their Photocatalysis Properties. J. Electron. Mater. 2018, 48, 278-285. [CrossRef]

25. Kannan, V.; Kim, H.J.; Park, H.C.; Kim, H.S. Single-Step Direct Hydrothermal Growth of $\mathrm{NiMoO}_{4}$ Nanostructured Thin Film on Stainless Steel for Supercapacitor Electrodes. Nanomaterials 2018, 8, 563. [CrossRef] [PubMed]

26. Kianpour, G.; Salavati-Niasari, M.; Emadi, H. Sonochemical synthesis and characterization of $\mathrm{NiMoO}_{4}$ nanorods. Ultrason. Sonochem. 2013, 20, 418-424. [CrossRef] [PubMed]

27. Liu, T.; Chai, H.; Jia, D.; Su, Y.; Wang, T.; Zhou, W. Rapid microwave-assisted synthesis of mesoporous $\mathrm{NiMoO}_{4}$ nanorod/reduced graphene oxide composites for high-performance supercapacitors. Electrochim. Acta 2015, 180, 998-1006. [CrossRef]

28. Umapathy, V.; Neeraja, P.; Manikandan, A.; Ramu, P. Synthesis of $\mathrm{NiMoO}_{4}$ nanoparticles by sol-gel method and their structural, morphological, optical, magnetic and photocatlytic properties. Trans. Nonferr. Met. Soc. China 2017, 27, 1785-1793. [CrossRef]

29. Liu, M.C.; Kong, L.B.; Lu, C.; Ma, X.J.; Li, X.M.; Luo, Y.C.; Kang, L. Design and synthesis of $\mathrm{CoMoO}_{4}-\mathrm{NiMoO}_{4} \cdot \mathrm{xH}_{2} \mathrm{O}$ bundles with improved electrochemical properties for supercapacitors. J. Mater. Chem. A 2013, 1, 1380-1387. [CrossRef]

30. Kianpour, G.; Soofivand, F.; Badiei, M.; Salavati-Niasari, M.; Hamadanian, M. Facile synthesis and characterization of nickel molybdate nanorods as an effective photocatalyst by co-precipitation method. J. Mater. Sci. Mater. Electron. 2016, 27, 10244-10252. [CrossRef]

31. Chua, C.K.; Pumera, M. The reduction of graphene oxide with hydrazine: Elucidating its reductive capability based on a reaction-model approach. Chem. Commun. 2016, 52, 72-75. [CrossRef] [PubMed]

32. Yang, Z.Z.; Zheng, Q.B.; Qiu, H.X.; Jing, L.I.; Yang, J.H. A simple method for the reduction of graphene oxide by sodium borohydride with $\mathrm{CaCl}_{2}$ as a catalyst. New Carbon Mater. 2015, 30, 41-47. [CrossRef]

33. De Silva, K.K.H.; Huang, H.H.; Yoshimura, M. Progress of reduction of graphene oxide by ascorbic acid. Appl. Surf. Sci. 2018, 447, 338-346. [CrossRef]

34. Zhuo, Q.; Zhang, Y.; Du, Q.; Yan, C. Facile reduction of graphene oxide at room temperature by ammonia borane via salting out effect. J. Colloid Interface Sci. 2015, 457, 243-247. [CrossRef] [PubMed]

35. Devi, M.M.; Sahu, S.R.; Mukherjee, P.; Sen, P.; Biswas, K. Graphene: A self-reducing template for synthesis of graphene-nanoparticles hybrids. RSC Adv. 2015, 5, 62284-62289. [CrossRef]

36. Bankar, P.K.; Ratha, S.; More, M.A.; Late, D.J.; Rout, C.S. Enhanced field emission performance of $\mathrm{NiMoO}_{4}$ nanosheets by tuning the phase. Appl. Surf. Sci. 2017, 418, 270-274. [CrossRef]

37. Feng, H.; Cheng, R.; Zhao, X.; Duan, X.; Li, J. A low-temperature method to produce highly reduced graphene oxide. Nat. Commun. 2013, 4, 1539. [CrossRef] [PubMed]

38. Du, M.; Sun, J.; Chang, J.; Yang, F.; Shi, L.; Gao, L. Synthesis of nitrogen-doped reduced graphene oxide directly from nitrogen-doped graphene oxide as a high-performance lithium ion battery anode. RSC Adv. 2014, 4, 42412-42417. [CrossRef]

39. Soni, M.; Kumar, P.; Kumar, R.; Sharma, S.K.; Soni, A. Photo-catalytic reduction of oxygenated graphene dispersions for supercapacitor applications. J. Phys. D Appl. Phys. 2017, 50, 124003-124011. [CrossRef] 
40. Ezeigwe, E.R.; Khiew, P.S.; Siong, C.W.; Tan, M.T. Synthesis of $\mathrm{NiMoO}_{4}$ nanorods on graphene and superior electrochemical performance of the resulting ternary based composites. Ceram Int. 2017, 43, 13772-13780. [CrossRef]

41. Ghosh, D.; Giri, S.; Das, C.K. Synthesis, characterization and electrochemical performance of graphene decorated with $1 \mathrm{D} \mathrm{NiMoO} 4 \cdot \mathrm{nH}_{2} \mathrm{O}$ nanorods. Nanoscale 2013, 5, 10428-10437. [CrossRef]

42. Liu, H.; Zhang, G.; Zhou, Y.; Gao, M.; Yang, F. One-step potentiodynamic synthesis of poly (1,5-diaminoanthraquinone)/reduced graphene oxide nanohybrid with improved electrocatalytic activity. Mater. Chem. A 2013, 1, 13902-13913. [CrossRef]

43. Peng, W.; Li, H.; Liu, Y.; Song, S. A review on heavy metal ions adsorption from water by graphene oxide and its composites. Mol. Liq. 2017, 230, 496-504. [CrossRef]

44. Li, Y.; Jian, J.; Xiao, L.; Wang, H.; Yu, L.; Cheng, G.; Sun, M. Synthesis of $\mathrm{NiMoO}_{4}$ nanosheets on graphene sheets as advanced supercapacitor electrode materials. Mater. Lett. 2016, 184, 21-24. [CrossRef]

45. Rajkumar, M.; Hsu, C.T.; Wu, T.H.; Chen, M.G.; Hu, C.C. Advanced materials for aqueous supercapacitors in the asymmetric design. Prog. Nat. Sci. Mater. 2015, 25, 527-544. [CrossRef]

46. Jiang, G.; Zhang, M.; Li, X.; Gao, H. NiMoO $@$ @ $\mathrm{Ni}(\mathrm{OH})_{2}$ core/shell nanorods supported on Ni foam for high-performance supercapacitors. RSC Adv. 2015, 85, 69365-69370. [CrossRef]

47. Budhiraju, V.S.; Kumar, R.; Sharma, A.; Sivakumar, S. Structurally stable hollow mesoporous graphitized carbon nanofibers embedded with $\mathrm{NiMoO}_{4}$ nanoparticles for high performance asymmetric supercapacitors. Electrochim. Acta 2017, 238, 337-348. [CrossRef]

48. Yang, J.; Liu, W.; Niu, H.; Cheng, K.; Ye, K.; Zhu, K.; Yan, J. Ultrahigh energy density battery-type asymmetric supercapacitors: $\mathrm{NiMoO}_{4}$ nanorod-decorated graphene and graphene $/ \mathrm{Fe}_{2} \mathrm{O}_{3}$ quantum dots. Nano Res. 2018, 11, 4744-4758. [CrossRef]

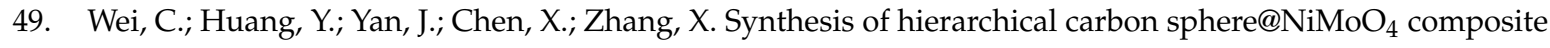
materials for supercapacitor electrodes. Ceram Int. 2016, 42, 15694-15700. [CrossRef]

50. Zhang, Z.; Liu, Y.; Huang, Z.; Ren, L.; Qi, X.; Wei, X.; Zhong, J. Facile hydrothermal synthesis of $\mathrm{NiMoO}_{4} @ \mathrm{CoMoO}_{4}$ hierarchical nanospheres for supercapacitor applications. Phys. Chem. Chem. Phys. 2015, 17, 20795-20804. [CrossRef]

51. Yang, S.; Zhang, K. Converting Corncob to Activated Porous Carbon for Supercapacitor Application. Nanomaterials 2018, 8, 181. [CrossRef] [PubMed]

52. Krishnan, S.G.; Ab Rahim, M.H.; Jose, R. Synthesis and characterization of $\mathrm{MnCo}_{2} \mathrm{O}_{4}$ cuboidal microcrystals as a high performance psuedocapacitor electrode. Alloy. Compd. 2016, 656, 707-713. [CrossRef]

53. Fang, L.; Wang, F.; Zhai, T.; Qiu, Y.; Lan, M.; Huang, K.; Jing, Q. Hierarchical CoMoO 4 nanoneedle electrodes for advanced supercapacitors and electrocatalytic oxygen evolution. Electrochim. Acta 2018, 259, 552-558. [CrossRef]

54. Miankushki, H.N.; Sedghi, A.; Baghshahi, S. Facile and scalable fabrication of graphene/polypyrrole/ $\mathrm{MnO}_{\mathrm{x}} / \mathrm{Cu}(\mathrm{OH})_{2}$ composite for high-performance supercapacitors. J. Solid State Chem. 2018, 22, 3317-3329. [CrossRef]

(C) 2019 by the authors. Licensee MDPI, Basel, Switzerland. This article is an open access article distributed under the terms and conditions of the Creative Commons Attribution (CC BY) license (http:// creativecommons.org/licenses/by/4.0/). 